\title{
The Impact of Social Relationship between CEO and CFO on Cash Holdings in Chinese Listed Firms
}

\author{
Zhiqiang Ye*, Xiaomeng Wang, Jiawen Yu, Yuqi Zhang \\ Department of Finance, School of Business, East China University of Science and Technology, Shanghai, China \\ Email: *yzq2011wzy@ecust.edu.cn
}

How to cite this paper: Ye, Z. Q., Wang, X. M., Yu, J. W., \& Zhang, Y. Q. (2021). The Impact of Social Relationship between CEO and CFO on Cash Holdings in Chinese Listed Firms. Modern Economy, 12, 764-774. https://doi.org/10.4236/me.2021.124037

Received: March 8, 2021

Accepted: April 17, 2021

Published: April 20, 2021

Copyright $\odot 2021$ by author(s) and Scientific Research Publishing Inc. This work is licensed under the Creative Commons Attribution International License (CC BY 4.0).

http://creativecommons.org/licenses/by/4.0/

\begin{abstract}
A company's cash holdings are closely related to its performance and market capitalization, as well as the decision preference and management mode of managers. Among the factors affecting cash holdings, the social relationship between the most two important executives of a company, CEO and CFO, plays an important role. Accordingly, this paper studies the influence of fellow villagers' relationship and alumni's relationship on cash holdings of listed companies, which not only enriches the literature about the impact factors of CEO-CFO social relationship, but also provides practical guidance for cash holding adjustments of listed companies.
\end{abstract}

\section{Keywords}

CEO-CFO, Social Relationship, Cash Holdings, Company Value

\section{Introduction}

Cash holding policy is the basis of financial policies, so how to optimize the allocation of the company's cash assets is a common concern of academia and enterprises. According to the agency theory, CEOs of listed companies hope to invest more cash, build a stronger business empire to increase their social reputation and income, and so hold less cash. But as the CFO of the company, his main duty is how to allocate cash assets more reasonably and prevent the company from financial distress in the future, and ensure the orderly progress of the company's investment, so need to retain more cash holdings. Therefore, the policy objectives of CEO and CFO are different, which leads to the conflict of cash holding policy.

This paper examines the impact of the social relationship between CEO and 
CFO on the cash holdings of Chinese listed companies. As complex "Guanxi" existing in China, the influence of social relations is very extensive, especially the relationship between fellow countrymen and alumni. If two people have the relationship of fellow countrymen or alumni, the psychological distance between them will be narrowed and the communication will be more convenient. Considering their duties, CFOs not only provide professional support to the companies' finances, but also have the responsibility to supervise CEOs. Being prudence, the CFO is more willing to increase cash holdings to reduce the risk of capital flow, while the CEO may sacrifice some capital flows for the earning growth, seeking profit maximization of the company. However, when the CEO and the CFO have a close social relationship, the CFO will be more likely to agree with the CEO's decisions and assist CEO strategically with professional knowledge. When CEO and CFO have conflict in cash holding policy objectives, due to the social relationship between them, $\mathrm{CEO}$ and CFO can better cooperate to reduce the agency cost of $\mathrm{CEO}$, and add the cash holding level of the listed company, so as to prevent the company from falling into financial distress in the future. Hence, the similar social background of CEO and CFO will challenge their mutual supervision to each other. Therefore, it is necessary to study the social relations between $\mathrm{CEO}$ and $\mathrm{CFO}$.

The existing literature focuses on how the characteristics, professional background, graduate schools and other indicators of CEO and CFO influence cash holdings and usage, while there are few researches on the CEO-CFO relationship, the alumni relationship, and even less researches on other social relationships such as the ownership relationship.

Cash holding is the basic indicators of a company. As one of the necessary conditions for a company's production and operation, it has a great impact on the company's efficiency. The amount of cash holdings plays a decisive role in the company's scale, risk tolerance and financing ability. Cash holdings and liquidity issues have a great impact on the company's finances. In the case of management's large cash holdings, the return on funds will have a certain negative impact. While enhancing the ability to resist risk, the probability of income is also reduced. At the same time, according to the trade-off theory and pecking order theory, cash holdings will affect the value of enterprises. The study on the influencing factors of cash holdings is of great significance to the study of enterprise value. Therefore, this paper studies the influence of social relationship between $\mathrm{CEO}$ and $\mathrm{CFO}$ on cash holdings. In this paper, taking cash holdings as the dependent variable, social relations between $\mathrm{CEO}$ and CFO as the independent variable, and controlling other irrelevant variables such as industry type, a mathematical model is established to study whether the social relations between $\mathrm{CEO}$ and CFO will have a significant impact on cash holdings.

The data selected in this paper come from various databases (including RESSET, CSMAR and other databases), which are used to screen and sort out most listed companies that have published the social relationship between CEO 
and CFO, expanding the research field of previous literature, and providing empirical support for the perspective and influence of social relationship of executives on enterprise value. At the same time, in a practical sense, it provides a reference for the company in terms of improving the company's value and performance, and has an incentive effect on better disclosing the information of the company's senior management team.

This paper proceeds as follows. Section 2 reviews the related literature and proposes research hypotheses. Section 3 presents research design. Section 4 shows the empirical results. Section 5 concludes.

\section{Literature Review and Research Assumptions}

\subsection{Literature Review of Social Relations}

Social relationship usually refers to the relationship between people formed in the process of production and living together. "Guanxi" always takes an important position in Chinese society, and various human relationships have impacts on social and economic development. Upper echelon theory suggests that managers' personal characteristics such as cognition, preference to a large extent determines the performance of the company. Compared with individual managers, the interaction between members of the senior management team is even more crucial to impact the company (Hambrick et al., 1996), and the social relationship between executives will also affect the company's business decisions.

In the existing literature, researches on the social relations among senior executives focus on their political relations, colleague relations and family relations, while only a few papers pay attention to the hometown- and alumni-relations.

In recent studies on alumni relationship, Xie and Li (2017) conclude that the similar school experience, growing memory and cultural gene from the same Alma mater emotionally link the alumni together with mutual identity and trust. Cohen and Frazzini (2008) believe that private information can be passed between fund managers and company executives through alumni relationship, thus affecting the allocation and investment returns of institutional investors. $\mathrm{Lu}$ and $\mathrm{Hu}$ (2014) confirm that the fellow relationship among the CEO and the board of directors increases the operational risk of enterprises. Yu et al. (2018) proves that the stronger the regional relationship between chairman and CEO is, the worse the internal control quality of listed companies will be. Zhang and Yuan (2020) argue that in mergers and acquisitions, although the CEO alumni relations is conducive to reduce the information asymmetry by getting more useful decision information, but it may promote the collusion of CEOs from both sides, leading to principal-agency problem. CEOs from both sides have plenty of motivation to maximize personal benefits against cooperate value. In details, the CEOs of acquirers seek to retain themselves or their team, and the CEOs of acquires seek compensation raise. $\mathrm{Hu}$ (2020) believes that the township does play a important role in the inefficient investment practice of enterprises, which is in 
the form of over-investment. It has passed a variety of robustness tests that the enterprise with the general manager and the chairman from the same town has lower investment efficiency.

\subsection{Literature Review of Cash Holding Policies}

This paper studies the impact of CEO-CFO social relationships on cash holdings of listed companies, which is an important financial index of enterprises. So the impact factors of enterprise cash holdings is also the object of this paper, in order to explain how the social relationship between CEO and CFO influences cash holdings of listed companies. The current empirical researches of cash holding impact factors mainly focus on those at the company level. Opler et al. (1999) empirically prove that the cash holdings have significantly positive relationship with cash flows, while negatively related with financial leverage, the difficulties in financing, dividend payments and etc. Martínez-Sola et al. (2018) explore that there exists positive correlation between cash holdings and short-term debt ratios, but negatively related with long-term debt rates. Hu and Jiang (2005) study listed companies in China from 1998 to 2002, and empirically conclude that the company size is positively related to cash holdings, and the liabilities, cash substitutes and the company age are negatively related to cash holdings. Yang and Sun (2007) find that cash holdings of enterprises is negatively related to financial leverage and net working capital, and is positively related to investment opportunities.

The level of cash holdings of listed companies will also be affected by corporate governance factors. Studies such as Yang (2008) claim that companies with greater management power have higher levels of cash holdings, but the lower value of cash holdings. Liao and Xiao (2009) show that corporate governance plays an important role in the company's cash holdings.

The personal characteristics of company executives can also impact the company's cash holdings. Xu et al. (2018) points out that the CFOs' abilities are related to cash holdings, that is, due to their moderate self-confidence, the CFOs with strong abilities believe that a major crisis is unlikely to happen, thereby it seems natural to reduce the preventive motivation a well as the cash holdings of companies. Shen (2018) lists that the education of executives is positively related to the company's cash holdings, while the age of senior executives is negatively related to cash holdings. In addition, the relationship between company executives also has an impact on the level of cash holdings of listed companies. Research by Chen Huangyue and Yu Huanmin (2018) shows that when the CEO and CFO have an alumni relationship, the value of the company's cash holdings increases significantly, hence increasing the company's cash holdings.

\subsection{Research Hypothesis}

According to current literature on the impact factors of listed companies' cash holdings, there are many complicated factors affecting the cash holdings of listed 
companies, including corporate governance, individual executives' background and experience, the macro- and enterprise-economic environment, the company capital structure and etc. It can be concluded that the personal characteristics of the company's executives impact the company's cash holding level in many ways, among which the social relationship between the CEO and the CFO is a widespread impact factor.

CEOs and CFOs play an important role in the operation and performance of listed companies. The CEO with the full name as the chief executive officer of the company is responsible for business decision-making and the daily affairs of the company, which is directly affecting the company's business development. As an important resource and value manager of the company, the CFO with the full name as the chief financial officer of the company, is mainly responsible for the company's financial management, project valuation, risk management, product development, strategic planning and other financial related affairs. As the core members of the executive team, the relationship of the CEO and the CFO tends to get closer. Their decision-making is important to the enterprise business development, and they are jointly responsible for the company's cash holding decisions. As the most basic and important financial index of the company, the realization of the value effect largely depends on the company's cash holding strategy chosen by the company managers and the cash using efficiency.

China is a relationship-based country, where social relationships much influence the economic life. Therefore, considering Chinese cultural and economic environment, as well as the important role of the CEO and the CFO in listed companies, it is necessary to study the social relationship between $\mathrm{CEO}$ and $\mathrm{CFO}$ of listed companies. Furthermore, to explain the impact of CEO-CFO social relationship on cash holdings of listed companies is of great significance to the operation and performance of the company.

However, the existing research on the cash holding value of listed companies focuses on product market competition, financing constraints, corporate governance mechanism and other internal and external environmental factors. Some papers involve the impact of the personal characteristics of company executives on cash holdings, but the $\mathrm{CEO}$ and $\mathrm{CFO}$, as the two important executives of the company, are rarely discussed, not to mention their social relationship and its impact on cash holdings. But the social relationship between the CEO and the CFO can affect the cash holding level of listed companies in various ways, for example, the social relationship between the $\mathrm{CEO}$ and the $\mathrm{CFO}$ affects the company's cash dividends, besides, whether the CFO enters the board of directors has impact on the cash holding decision of listed companies, which is jointly decided with the CEO.

Therefore, we intend to analyze the impact of the social relationship between the CEO and the CFO on the company cash holding value. Accordingly, the research hypothesis is proposed as below.

Hypothesis 1: The CEO-CFO social relationship increases the cash holding level of listed companies. 


\section{Research Design}

\subsection{Data Selection and Model Setting}

In order to study the influence of CEO-CFO social relationship on corporate cash holdings, this paper takes the searchable relationship of senior executives in listed companies as the research objective. To reduce data gaps and make the annual review of the data, we choose the data from January, 2002 to December, 2019. The data mainly comes from CSMAR and RESSET which contain the Chinese listed firms' finance and accounting data, and the missing data of the CEO-CFO relationship is hand-collected from the senior executive information on the website of Sohu finance. After comparative analysis, we eliminate the invalid and missing data, and obtain 33,740 financial information about the relationship of CEOs, CFOs and their companies. Based on our research hypothesis, this paper puts forward the following empirical model:

$$
\begin{aligned}
\text { Cash }_{i, t}= & \alpha+\beta_{1} * \text { relationship }_{i, t}+\beta_{2} * \text { cf }_{i, t}+\beta_{3} * \text { Lev }_{i, t} \\
& +\beta_{4} * \text { Size }_{i, t}+\beta_{5} * N w c_{i, t}+\beta_{6} * \text { Capex }_{i, t}+\beta_{7} * \text { Growth }_{i, t} \\
& +\beta_{8} * \text { DummyDiv }_{i, t}+\sum \text { Industry }+\sum \text { Year }+\varepsilon_{i, t}
\end{aligned}
$$

We use cash holdings as the dependent variable to measure the market value and performance of listed companies. There are three reasons. Firstly, accordingly to the static trade-off theory, the company has the optimal debt financing, and the cash holdings of the company is related to the external financing costs. Second reason is the asymmetric information theory. The asymmetric information not only makes external financing very difficult, but also increases the cost of external financing. Hence, higher cash holdings increase the internal financing, which is conducive to reducing costs. Thirdly, the agency theory and free cash flow hypothesis hold that the interests of shareholders and agents are inconsistent, so some agents will maximize their own interests to abuse free cash by putting free cash into the projects with negative net present value easily. In this paper, cash holdings are divided into two components, one is cash 1, which is the ratio of cash value to total assets, and the other is cash 2, which is the sum of cash and short-term investments divided by total assets.

The independent variable Relationship is the relationship between the CEO and the CFO, which is marked as 1 when they share coeducation relationship or countryman relationship, and 0 otherwise. This variable mainly indicates whether there is social relationship between the two: countryman relationship or alumni relationship. The control variables are the operating cash flow $(C f)$, asset-liability ratio Lev, company Size size, net working capital Nwc, capital expenditure Capex, operating income Growth rate, dividend policy DummyDiv. These seven indicators further explore whether social relations between CEO and CFO have different effects on cash holdings when operating cash flow, asset-liability ratio, company size, net working capital, capital expenditure, growth rate of operating income and dividend policy are different. Table 1 presents the detail definition of variables. 
Table 1. Definition variables.

\begin{tabular}{|c|c|c|c|}
\hline $\begin{array}{l}\text { Variable } \\
\text { type }\end{array}$ & $\begin{array}{l}\text { Variable } \\
\text { symbol }\end{array}$ & Variable name & Variable definition \\
\hline \multirow{2}{*}{$\begin{array}{l}\text { dependent } \\
\text { variable }\end{array}$} & Cash1 & Cash holdings & cash/total assets \\
\hline & Cash2 & Cash holdings & $\begin{array}{c}\text { holdings (cash }+ \text { short }- \text { term investments }) \\
\text { /total assets }\end{array}$ \\
\hline \multirow[t]{4}{*}{$\begin{array}{l}\text { independent } \\
\text { variable }\end{array}$} & Relationship & $\begin{array}{l}\text { CEO-CFO } \\
\text { social relations }\end{array}$ & $\begin{array}{l}\text { When the CEO and CFO graduate school or } \\
\text { place of birth are the same, Relationship }=1 \text {, } \\
\text { otherwise Relationship }=0\end{array}$ \\
\hline & $\mathrm{Cf}$ & Operating cash flows & Operating cash flows/total assets \\
\hline & Lev & Gearing ratio & Total liabilities/total assets \\
\hline & Size & Company size & $\ln$ (Total assets) \\
\hline \multirow{4}{*}{$\begin{array}{l}\text { Control } \\
\text { variable }\end{array}$} & Nwc & Net working capital & $\begin{array}{l}\text { (current assets-current liabilities-cash) } \\
\text { /total assets }\end{array}$ \\
\hline & Capex & $\begin{array}{c}\text { Capital } \\
\text { expenditure }\end{array}$ & $\begin{array}{c}\text { [Year } t \text { (fixed assets }+ \text { intangible assets }+ \text { other } \\
\text { non-current assets) }- \text { Year } t-1 \text { (fixed assets }+ \\
\text { intangible assets }+ \text { other non-current assets) }\end{array}$ \\
\hline & Growth & $\begin{array}{l}\text { Revenue } \\
\text { growth rate }\end{array}$ & $\begin{array}{l}\text { (revenue for Year T-revenue for Year } t-1 \text { ) } \\
\qquad / \text { revenue for Year } t-1\end{array}$ \\
\hline & dummydiv & Dividends paid & $\begin{array}{l}\text { when cash dividends are paid, dummdiv }=1 \text {; } \\
\text { otherwise, dummdiv }=0\end{array}$ \\
\hline
\end{tabular}

\subsection{Statistical Description of the Data}

Table 2 presents the descriptive statistical result for each variable. During the studied period, the cash holding proportion in the first cash holdings of Chinese listed companies is $18.73 \%$ of total assets, and the second cash holding proportion is $19.09 \%$. These two close numbers indicate that cash holdings of Chinese listed companies are mainly in cash form with small amount in short-term investment. The proportion of alumni relationship or fellow relationship between $\mathrm{CEO}$ and CFO from Chinese listed companies is $22.79 \%$, indicating the importance of the social relationship between CEO and CFO in listed companies in studying cash holding. The cash dividend payment rate of $67.09 \%$, which shows that most Chinese listed companies pay cash dividends, the proportion of operating cash flow to total assets is relatively small as $4.26 \%$, and the ratio of assets to liabilities is $51.31 \%$, indicating that the ratio of assets to liabilities of listed companies in China is high.

\section{Empirical Results}

Table $3(\mathrm{~b})$ is the regression result of how CEO-CFO alumni relationship and hometown relationship influence the enterprise cash holdings. In the first regression with the dependent variable not including the cash holdings of short-term investment, the CEO-CFO's alumni- and hometown-relationship have positive impact on the cash holdings of the business at $1 \%$ significance level with the 
coefficient as 0.0118. It shows that the cash holding value of the companies with CEO-CFO alumni or hometown relationship is $1.18 \%$ higher than the companies without such social relationship, which fits with our expectations. When there is a social relationship between the CEO and CFO, the communication between the two is more smooth, the decision-making is more effective, which has positive impact on the company's cash holdings.

Table 2. Statistical description of variables.

\begin{tabular}{ccccc}
\hline stats & cash1 & cash2 & relationship & size \\
\hline mean & 0.1873 & 0.1909 & 0.2279 & 21.8469 \\
p25 & 0.0871 & 0.0889 & 0 & 20.9097 \\
p50 & 0.1455 & 0.1484 & 0 & 21.6844 \\
p75 & 0.2439 & 0.2482 & 0 & 22.5901 \\
sd & 0.1460 & 0.1483 & 0.4195 & 1.3444 \\
N & 33,740 & 33,740 & 33,740 & 33,740 \\
stats & growth & dummydiv & cf & leverage \\
mean & 38.1516 & 0.6709 & 0.0426 & 0.5131 \\
p25 & -1.5252 & 0 & 0.0033 & 0.2816 \\
p50 & 12.1055 & 1 & 0.0434 & 0.4480 \\
p75 & 28.6152 & 1 & 0.0874 & 0.6115 \\
sd & 1310.2150 & 0.4699 & 0.1747 & 5.6340 \\
N & 33,740 & 33,740 & 33,740 & 33,740
\end{tabular}

Table 3. The regress results.

\begin{tabular}{|c|c|c|c|c|}
\hline & \multicolumn{2}{|c|}{ (a) Cash2 } & \multicolumn{2}{|c|}{ (b) Cash1 } \\
\hline & Coefficient & $t$ & Coefficient & $t$ \\
\hline relationship & $0.012^{* * *}$ & 6.43 & $0.0118^{* * *}$ & 6.60 \\
\hline size & $-0.020^{* * *}$ & -30.28 & $-0.020^{* * *}$ & -30.77 \\
\hline$n w c$ & $0.034^{* *}$ & 1.98 & $0.034^{* *}$ & 1.98 \\
\hline growth & 0.000 & 0.21 & 0.000 & 0.04 \\
\hline dummydiv & $0.062^{* * *}$ & 33.08 & $0.062^{* * *}$ & 33.26 \\
\hline$c f$ & 0.046 & 1.59 & 0.047 & 1.59 \\
\hline leverage & 0.031 & 6.43 & 0.030 & 1.93 \\
\hline capexpdm & 0.000 & -30.28 & 0.000 & 1.69 \\
\hline Year fixed effect & \multicolumn{2}{|c|}{ yes } & \multicolumn{2}{|c|}{ yes } \\
\hline Industry fixed effect & \multicolumn{2}{|c|}{ yes } & \multicolumn{2}{|c|}{ yes } \\
\hline $\mathrm{F}$ & \multicolumn{2}{|c|}{105.40} & \multicolumn{2}{|c|}{103.07} \\
\hline $\mathrm{P}>\mathrm{F}$ & \multicolumn{2}{|c|}{0.000} & \multicolumn{2}{|c|}{0.0000} \\
\hline $\mathrm{R}^{2}$ & \multicolumn{2}{|c|}{0.231} & \multicolumn{2}{|c|}{0.225} \\
\hline obs & \multicolumn{2}{|c|}{33,740} & \multicolumn{2}{|c|}{33,740} \\
\hline
\end{tabular}

${ }^{*},{ }^{* *}$, and, ${ }^{* * *}$ indicate statistical significance at $10 \%, 5 \%$, and $1 \%$ levels, respectively. 
For the control variables in the regression, we take the company size and established years into account, because companies with different established years and sizes may have different cash holding policies. Meanwhile, we consider the company's net working capital, operating cash flow and capital expenditure, which have positive impacts on the company's cash holdings based on the regression results. Dividend distribution factors of the company also worth our considerations. Companies that pay dividends every year may tend to hold more cash. For the company's debt-to-asset ratio, companies with higher debt-to-asset ratio will have more pressure to repay loans and may need more cash reserves.

Table 3(a) shows the regression results of cash holdings only including cash. The regression results of cash1 and cash2 are similar. In the regression of cash2, the $\mathrm{R}$ squared value is larger, suggesting increasing explanation power of the $\mathrm{CEO}$ and CFO relationship for cash holdings level. The coefficients imply the similar impact power on cash holdings, so both cases statistically prove that the CEO-CFO social relationship has significantly positive impact on the company's cash holdings.

\section{Conclusion}

This paper mainly studies the impact of the alumni and hometown relationship between CEO and CFO on cash holdings of listed companies, which is one of the most important financial indicators of listed companies. In previous studies on the impact factors of cash holding level, there is little research on individual characteristics, such as social relationship. Based on the social relationship between CEO and CFO, this paper selects sample data from 2002 to 2019 to test the influence of social relationship on cash holdings. We empirically find that the social relationship between CEO and CFO has significant positive impact on the cash holding level of listed companies. Theoretically, when there exists the CEO-CFO social relationship, their decisions on the company's cash holding level are influenced to a certain extent. Specifically, when the CEO or chairman of the board of directors in a listed company is from the same hometown or same school with the CFO, the company's cash holdings increase, thus having higher abilities to resist risks.

Based on the perspective of social relations, this paper takes the social relations of CEO-CFO as the breakthrough point to explore the influence of alumni relations and fellow countrymen relations on cash holdings of listed companies. It enriches the research in relevant fields and puts forward the following two policy references for listed companies.

Firstly, the listed companies should implant the management of CEO-CFO social relations into the scope of business management. This paper studies the impact of social relationship between CEO and CFO on cash holdings of listed companies, which provides a reference for companies to improve their cash holdings from the perspective of managing social relationship between CEO and CFO. Through empirical research, we find that the social relationship between 
$\mathrm{CEO}$ and CFO can effectively promote their communication, so that enterprises can form correct cash holding decisions, which improves the corporate cash holding level. Therefore, based on the research of this topic, it is suggested that listed companies should appropriately implant the management of the relationship between CEO and CFO into the operation and management of the enterprise, so as to have a positive impact on the cash holdings of the enterprise.

Secondly, the listed companies should disclose more complete information about the senior management team. This paper analyzes the background characteristics of the two top executives, the $\mathrm{CEO}$ and the $\mathrm{CFO}$ of listed companies, to motivate companies to disclose more perfect information of the senior management team. At present, the annual reports of listed companies disclose little about the background of the senior management team (such as position, age, educational background, graduate school, overseas experience, etc.), resulting in the increased possibility of making wrong decisions about listed companies due to the absence of the relevant background of their senior management team. The relevant data used in this research contains detailed personal information of senior management team, which provides a good demonstration for other companies in information disclosure.

Thirdly, although the social relationship between CEO and CFO is conducive to increasing the cash holding level of listed companies and reducing the company's operational risk, it should also prevent collusion between them and damage the company's interests. Therefore, when hiring CFO, the board of directors should consider the possible social relationship between $\mathrm{CEO}$ and $\mathrm{CFO}$, strengthen the incentive and supervision of CFO, clarify the company goal of CFO, and ensure that the common goal between $\mathrm{CEO}$ and $\mathrm{CFO}$ is to maximize the company value.

Limited by the data sources, this paper only discusses the relationship between fellow countrymen and alumni, but the more extensive relationship, such as colleagues or joining the same social organization (some clubs), and these relationships are more intimate than those between fellow countrymen and alumni. Therefore, future research can use the big data platform to dig out more extensive social relations between $\mathrm{CEO}$ and $\mathrm{CFO}$, and make more accurate empirical analysis according to these extensive social relations, so as to enhance the robustness of the research results.

\section{Conflicts of Interest}

The authors declare no conflicts of interest regarding the publication of this paper.

\section{References}

Chen, H. Y., \& Yu, H. M. (2018). The Effect of CEO-CFO Alumni Relationship on the Value of Corporate Cash Holdings. Accounting Forum, 17, 73-86.

Cohen, L., \& Frazzini, R. (2008). Economic Links and Predictable Returns. The Journal of 
Finance, 63, 1977-2011.

Hambrick, D. C., Cho, T. S., \& Chen, M. J. (1996). The Influence of Top Management Team Everything Considered on Firm's Competitive Move. Administrative Science Quarterly, 41, 659-684. https://doi.org/10.2307/2393871

Hu, G., \& Jiang, Y. (2005). The Determinants of Cash Holdings Decision-New Evidence from B-Share Companies. Journal of Hunan University (Social Science Edition), 19, 49-54.

$\mathrm{Hu}$, J. (2020). The Relationship between Hometownship and Firm Investment Efficiency: Empirical Evidence from Chinese Public Companies. Journal of Shanxi University of Finance and Economics, 42, 98-112.

Liao, L., \& Xiao, Z. (2009). Does Corporate Governance Affect Corporate Cash Holdings-Empirical Evidence from Chinese Listed Companies. China Industry Economics, No. 6, 98-107.

Lu, Y., \& Hu, J. (2014). The Influence of "Fellow Township" Relationship between CEO and Directors on the Risk Level of Chinese Listed Companies. Management World, No. 3, 131-138.

Martínez-Sola, C., García-Teruel, P. J., \& Martínez-Solano, P. (2018). Cash Holdings in SMEs: Speed of Adjustment, Growth and Financing. Small Business Economics, 51, 823-842. https://doi.org/10.1007/s11187-018-9990-y

Opler, T., Pinkowitz, L., Stulz, R., \& Williamson, R. (1999). The Determinants and Implications of Corporate Cash Holdings. Journal of Financial Economics, 52, 3-46.

Shen, W. (2018). Background Characteristics, Property Rights and Cash Holdings of Executives. Journal of Anhui Radio \& TV University, No. 4, 29-37.

Xie, S., \& Li, Y. (2017). The Influence of Alumni Relationship between Senior Executives and Signature Certified Public Accountants on Audit Opinion: Empirical Evidence from China Securities Market. Contemporary Finance and Economics, No. 6, 109-119.

Xu, X., Li, X., \& Li, W. (2018). CFO Ability and Corporate Cash Holding: A Study Based on the Upper Echelon Theory. Modern Finance and Economics-Journal of Tianjin University of Finance and Economics, No. 11, 130-145.

Yang, J., \& Huang, L. (2008). Decision on Cash Holding between Controlling Shareholders and Listed Companies. Research on Economics and Management, No. 7, 77-81.

Yang, X., \& Sun, J. (2007). A Positive Study on the Determinants of Corporate Cash Holdings: The Empirical Evidence from Listed Companies of China. Nankai Business Review, 10, 47-54.

Yu, J., Jin, X., \& Liang, S. (2018). Research on the Governance Effect of Executives' Geographical Relationship: Based on the Investigation of Internal Control Quality. Accounting Research, No. 6, 78-85.

Zhang, Q., \& Yuan, T. (2020). Does CEO Alumni Relationship Influence Merger and Acquisition Decision and Effect. Journal of Shanghai University of Finance and Economics, 22, 82-96. 